\title{
Inkarrí: az andokbeli történelem keresése Flores Galindo gondolatkísérlete az andokbeli történeti identitás megújítására (Javier Zea)
}

Jelen írás az andokbeli identitás kapcsán a történeti identitást és az embereknek a történelemhez való viszonyát tárgyalja, elsôsorban Peruban.

Nagyon hosszú idôn keresztül volt egy olyan általános elfogadottnak tekintett, ún. hivatalos történelemkép, amelyet az általános iskolákban, illetve középiskolákban és magasabb szintú oktatási intézményekben is tanítottak. Ez a történelemfelfogás az európai történelem fogalmait és kategóriáit vették át és használta az andokbeli társadalomtörténet leírására. Például, az Inka társadalmat úgy festették le, mint egy rendi társadalmat, amiben volt egy király, egy nemesség, egy klérus és természetesen a nép. Ez a hivatalos történetírás nem tárgyalt viszont például olyan kategóriákat, mint reciprocitás vagy redisztribúció, amelyek, Polányi Károly (1957) nyomán, az andokbeli közösségeket leíró történeti antropológiai szakirodalom alapvetô fogalmai.

Egy másik példa az andokbeli vallásnak vagy vallásosságnak a példája. A történelemkönyvek jellemzôen úgy tárgyalják a prekolumbiánus vallásosság témáját, hogy volt egy Isten, és ez az istenség, ez a Napnak felelt meg (Inti), tehát a Napistent tisztelték az Inkák. Ez a fajta megközelítés megint valahol az európai képnek az átvétele: az európai egyistenhit andokra vonatkozó értelmezése, azzal a különbséggel, hogy a katolikus egyházban elfogadott Istent azt megfeleltették a Napnak, illetve a Napistennek. Valójában az andokbeli vallásosság nemcsak az egyistenképzetet nem tartalmazta, hanem ezekból a teremtô Isten fogalma is hiányzott. Az andokbeli istenség- 
képzet inkább valami rendezô, vagy szervezô erôvel rendelkezik, aki a káoszból alakít ki valamit. Éppen azért, mert nem létezik a semmibốl valamit teremtố Istennek a képe, a mi világunkra annyira jellemzô unlineáris világkép helyett is valami ciklikus, önmagába visszaforduló idốképet ismertek (és ismernek) az Andok ôshonos közösségei. Ez utóbbit azonban a hivatalos történetírás nem tárgyalja (lásd pl. Pease 1982: 9-24).

Egy harmadik példa: október Amerika-szerte úgy ismert, mint Amerika fedezésének a hónapja. A perui történelemkönyvek, amelyekbő́l magam is tanultam, Amerika fölfedezését kiemelten tárgyalták. A felfedezés mint kifejezés régóta szálka az ôshonos-mozgalmak, illetve az andokbeli megújulási mozgalmak szemében, amelyek úgy vélik, hogy ha felfedezésrốl beszélünk, akkor eleve két fölfedezésról kellene beszélni: Amerika fölfedezése az európaiak által, illetve az európaiak felfedezése, ugye, az amerikaiak által. Újabban már vannak ilyen könyvek, amelyek nem felfedezésként tárgyalják az 1498. évi októberi eseményeket, hanem a XVI. századi indián és spanyol érintkezésekrôl és kölcsönhatásokról írnak.

Egy következô példa a függetlenség kikiáltása, azaz a spanyoloktól való függetlenség kérdése. A hivatalos történetírás függetlenségi háborúkról ír, amelyek meghozták a latin-amerikai országok (köztük Peru és Bolívia, illetve idôvel Ecuador) függetlenségét. Néhány újabb tanulmány viszont inkább úgy tárgyalja ezeket az 1800-as évek eleji eseményeket, mint egyfajta hatalomváltást ezeknek a területeknek az életében (Bonilla 1972:16-30). A hatalom a „Penisulares”, azaz félszigetiek kezébôl (így nevezték az 1800-as évek elején a gyarmatokon a spanyolországi spanyolokat) a kreolok kezébe került, akik ugyanúgy spanyolok, illetve spanyol származásúak voltak. Ám közben a gyarmati rendszer struktúrája és az indiánok kizsákmányolása alig változott. Sok történész szerint az igazi változást nem a függetlenségi háborúk jelentették, hanem II. Tupac Amaru felkelése, illetve fellépése a politikai szinten, negyven évvel a felszabadítási háborúk elôtt. Ez egy valódi függetlenséget jelentett volna, illetve 
erre való kísérletnek volt értékelhetô. Csak hát ez a kísérlet óriási kudarccal végzôdött. Ebben a kontextusban érdemes II. Tupac Amaru életét és halálát felidézni.

Emlékeztetôként: negyven évvel Pizarro hadjárata és az Inka Birodalom bukása után, azaz 1572-ben a spanyol alkirály, Toledo csapatai rövid harc után bevették a keleti ôserdôben fekvô Vilcabambát, azt az erôdítményt, ahová a spanyoloknak be nem hódolt Inkák menekültek. Az akkor alig 16 éves uralkodót, az ifjú Tupac Amarut, akinek fejére épp azokban a napokban szállt volna az inka korona (már, ha lett volna ilyen tárgy), kisvártatva felnégyelték Cusco fôterén. Bô kétszáz évvel késôbb, 1780-ban egy José Gabriel Condorcanqui nevú kuraka (azaz indián származású nemes), két spanyol adószedố zaklatásait megunva, megölette óket a birtokán, Tungasucában, és ezzel kirobbantotta a spanyolok elleni felkelést, amely hamarosan az Andok egész térségére kiterjedt. Condorcanqui bejelentette, hogy ô az utolsó Inka leszármazottja, és felvette a II. Tupac Amaru nevet. 1781-ben, amikor az Andok központi területén leverték a fölkelést, II. Tupac Amarut ugyanúgy Cusco föterén négyelték fel, mint elôdjét, annak ellenére, hogy abban a korban a felnégyelés mint kivégzési módszer, távolról sem volt bevett gyakorlat. A spanyol alkirályi hatalom azt demonstrálta, visszautalva a XVI. századi eseményekre, hogy így végzik a tupacamaruk (Golte 1980).

Az 1990-es években több társadalmi, gazdasági és politikai folyamat vezetett oda, hogy a hivatalos felfogás megváltozzék. Az egyik legfon tosabb tényezô a nagy mértékú belsố migráció: az az országon belüli migráció, amelynek a keretében az 1940-es, 50-es évektôl kezdve nagyon sok falusi, andokbeli ember (ún. serrano, a Sierra, azaz hegyvidék szóból) költözött a tengerparti nagyvárosokba. Lima 20 év alatt 300 ezer lakosú városból 3 milliós várossá nôtt a 60-as évekig, napjainkban pedig (az elôvárosokkal együtt) már 9 millió lakosa van. Hasonló folyamatok mentek végben az ecuadori Guayaquil és Quito esetében is (Golte 1987). Ez a belsô migráció nagy társadalmi változást is hozott az Andok életében, sôt, egyes történészek szerint 
a spanyolok megérkezése óta ez a legnagyobb társadalmi változás az Andok történetében (Matos Mar 1980). Már csak azért is, mert ezek szerint a történészek szerint a függetlenség kivívása nem jelentett nagy változást az Andok életében. Ez elốtt a migrációs folyamat eloótt Lima gyakorlatilag az Andok térségétôl függetlenül élte a maga életét. Korabeli híradások és nagyon sokak megfogalmazása szerint Lima közelebb volt New Yorkhoz vagy Párizshoz, mint a Ayacuchóhoz vagy Cuscóhoz.

Egy következó ilyen hatás az, hogy nagyon sok andokbeli származású ember egyetemre került, tanulhatott. Amikor tanulmányaik során találkoztak a hivatalos történelemképpel, akkor azt érezték, hogy ez nem az, amit ók gondoltak a saját hagyományaikról, a saját történetükrôl. Megjelent az igény egy új történetírásra. Néhányan az új generációból azzal bélyegezték meg a hivatalos történetírást, hogy ez a gyôztesek történetírása (Kapsoli 2001). Meg kéne írni egy másik történelmet is: a legyôzöttek szemszögéból. Kialakult egy történészi mozgalom: menjünk el újra az Andok térségébe, nézzük meg az ottani archívumokat új szemmel. Eközben érdekes kölcsönhatás alakult ki az antropológusok és a történészek munkája között. Ez alapján kezdett el kialakulni egy újabb diszciplína, az etnohistória (Castelli 1981). Az etnohistória a XVI-XVIII. századi levéltári iratokból, anyakönyvekból és krónikákból származó adatokat veti egybe a néprajzosok/antropológusok által gyújtött információkkal. Ez az újfajta történetírás jelentôs mértékben fölülírta mindazt, amit korábban gondoltak. Például az, hogy a társadalmi kapcsolatok jelentôs mértékben redisztribúción és reciprocitáson alapulnak. Vagy az, hogy a teremtố Isten helyett egy rendezố Istennek a fogalma került a felszínre.

Térjünk vissza egy nagyon karakteres elemre, a nemzeti függetlenség kérdésére, amelyet a hivatalos történetírás a legnehezebben ad fel, és amelynek megítélése egészen napjainkig nem egy eldöntött kérdés. Peru, Ecuador vagy Bolívia nemzeti ünnepe egyaránt a függetlenség kikiáltásának a napja. Viszont az én személyes benyo- 
másom is az, hogy függetlenül hivatalos ünnepségektôl és attól, hogy nagyon sok társadalmi szervezet tart rendezvényeket ezen alkalommal, az embereket nem motiválja a függetlenség napja.

Az új történészgeneráció tagjai közül egy kiemelkedố személyiséget szeretnék bemutatni, a sajnos fiatalon, 42 évesen elhunyt Flores Galindo-t, aki példát mutatott arra, hogy miként lehet újraírni az andokbeli történelmet. Fómúvének címe: buscando un Inca, azaz magyarul „Egy inkát keresendő”. (Flores Galindo 1988: 25-33). A címbeli utalás nem szó szerint értendô, azaz nem tényleges személyben egy Inkát akar a szerzố felkutatni, hanem egy új út, az eddigieknél igazabb, az andokbeli kultúrához közelebb álló történeti identitás keresésére biztat. A könyv azzal a felütéssel kezd, hogy az andokbeli emberekben van egy ûr, van egy hiányérzet azért, mert az a történetírás, amit tanulnak, nem fejezi ki az ó érzéseiket.

A mú alcíme: Utopia Andina. Az utópia a perui konyhanyelvben valami megvalósíthatatlant jelent, Flores Galindo viszont az eredeti, Morus Tamás-i értelemben használja, mint olyan ideális hely, ahova vágyunk, amirôl nem is tudjuk biztosan, hogy létezik-e. A könyv célja, hogy a hivatalos történelemképpel szemben, amivel az Andok lakói nem tudnak azonosulni, építsünk föl egy olyan világot, amely megfelel a mai andokbelieknek. És ennek az új történetírásnak a felfedezés a fố küldetése: fölfedezni azt, hogy mire is vágynak az emberek.

A könyv egyik fejezete az Inkarrímítosz bemutatásáról szól (Flores Galindo, 1988:47-53). Az inkarríra vonatkozóan antropológusok és történészek az Andok nagyon-nagyon távoli szegleteiben gyújtötték ugyanazt a történetet. Az inkarrí mítosz arról szól, hogy az utolsó Inkának, tehát a felnégyelt és lefejezett Tupac Amarunak (de ez nincs nevesítve a mítoszban) a testrészeit széthordták a birodalom különbözô szegleteibe. A testrészeket késôbb eltemették a birodalom távoli pontjain. A mítosz szerint ezek a testrészek a föld alatt nem enyésztek el, hanem életre és vándorútra keltek. Vándorútjuk célja, hogy a föld alatt megkeressék egymást, és egyesüljenek. Külö- 
nösen keresik az elásott fejet, amely Cuscóban van. A mítosz szerint eljön majd az a pillanat, amikor ez a keresés sikeres lesz, tehát minden testrész megtalálja a fejet, és akkor a test újra feltámad, és dicsôséges király lesz belôle, mely elkergeti a spanyolokat: ez lesz egyúttal az andokbeli kultúrának is a föltámadása.

Ez átvezet ahhoz a gondolathoz, hogy a teremtố Isten képe helyett az Andokban egy rendezô Istent képzeltek el. Egy andokbeli felfogás szerint ugyanis a spanyolok megérkezésétốl a test egymásra találásáig tartó idôszak egy káosz-idôszak Ez a káosz-idôszak, amelyben most élünk, egy rendezô-Istenre vár, amelyik majd egyszer rendet tesz. Az inkarrí ennek az új istennek a neve. Ha megnézzük etimológiailag, akkor ennek a szónak ugye két gyöke van, az inka és a rey, azaz király (spanyolul). Kecsuául ez úgy is mondható, hogy Pachacuteq, mint a Földmozgató vagy Világrendezô. (Flores Galindo, 1988: 70-77).

Flores Galindo 1986-ben fejezte be a könyve kéziratát. Bár sok folyamatot jól látott, még többet jelzett elôre, nem láthatta át ezeknek a folyamatoknak a végét. Az azóta eltelt években, fóleg a kilencvenes évek második felében és az új évezred elsố évtizedében a perui történészek olyan történeti hagyományokhoz nyúltak vissza, melyek a hivatalos vagy ún. magas történelemben nem kerültek tárgyalásra, hanem el voltak dugva valahol a népi hagyományokban. Igaz, hogy az inkarrí még nagyon sok perui számára nem érkezett el, de a keresés már elkezdôdött az Andok társadalmában. Visszautalva a mítoszra, olyan, mintha a testrészek már nem valahol a föld alatt, hanem a föld felszínén, mindenki számára nyilvánvalóan keresnék egymást.

A hetvenes-nyolcvanas években az Andok még egyáltalán nem került média-reprezentációra a az elektronikus vagy írott sajtóban. A perui tévécsatornák nézói csodálkozhattak, mert az utca népének sötét bôrú, fekete hajú vonásaival szemben szinte csak a szốke, kék szemú emberek kerülhettek a képernyốre. A legnagyobb nézettségú csatornákon, kereskedelmi adókon még most is így van, mégis, napjainkra a helyzet változott: az andokbeli kultúra már nem tabutéma, 
lehet tárgyalni, sốt, sok órán keresztül tárgyalják is. Sok a kecsua nyelvú helyi rádióadó, még több a spanyol nyelvú, de indián közösségnek sugárzó televízió, rádió.

Az andokbeliség egyre inkább megjelenik a politikában is, és nemcsak helyi választásokon, hanem az országos politikában, ha más nem, legalább a frazeológia szintjén. Bolíviában indián politikai párt nyerte meg a választásokat, Peruban pedig a mostani elnök mesztic származású. Az elôzó ciklusban Toledo elnök indián származású volt, aki, amikor megnyerte a választásokat, sok szimbolikus gesztusban is kifejezésre juttatta az ország indián gyökereit. Elnöki beiktatását például nem Limában, a fótéren, az elnöki palota elôtt tartotta (mint ez szokás volt a köztársaság kikiáltása óta), hanem Machu Picchuban, és a szertartást egy pap helyett egy sámán vezette le.

Az inkát tehát már keresik az Andokban. Ez a keresés azonban nem a megszépített múlt felé való visszakanyarodást jelent (mint tették ezt a harmincas évek „indigenista” mozgalmának képviselői), hanem épp ellenkezôleg: egyfajta andokbeli jövôkép, egyfajta jövóbeli idea megalkotásáról van szó. Egy olyan egyensúly megteremtését tûzi ki célul a könyv, amelyben az andokbeliség, amelyik egy meghatározó többség az Andok országaiban, megfelelố reprezentációhoz juthat.

\section{Irodalom}

- Bonila, Heraclio 1972: La independencia en el Perú. Instituto de Estudios Peruanos. Lima. 201 pp.

- Castelli, Amalia 1981: Etnohistoria y Antropología Andina. Museo Nacional de Historia. Lima. 310 pp.

- Flores Galindo, Alberto 1986: Buscando un Inka. Editorial Horizonte. Lima. 1986. 437 pp.

- Golte, Jürgen 1980: Repartos y Rebeliones. Instituto de Estudios Peruanos. Lima. 256 pp. 
- Golte, Jürgen és Norma, Adams 1987: Los caballos de Troya de los invasores. Instituto de Estudios Peruanos . Lima. 232 pp.

- Kapsoli, Wilfredo 2001: Historia e Historiadores. Universidad Ricardo Palma, Lima. 252 pp.

- Matos Mar, José 1980: Desborde Popular y Crisis del Estado. Instituto de Estudios Peruanos. Lima . 215 pp.

- Pease, Franklin 1982: El Pensamiento Mítico. Biblioteca del Pensamiento Peruano. Lima. 235 pp.

- Polanyi, Karl 1957: The Economy as Isntitued Process. In: Polanyi, Karl, Conrad M. Arnesberg and Harry W. Pearson (eds.): Trade and Markets in the Early Empires. Glencoe, Ill.: The Free Press 